Volume 1

Issue 1 Transformative Possibilities:

Transcending Interlocking Boundaries

\title{
The Clerical Wife: Medieval Perceptions of Women During the Eleventh- and Twelfth-Century Church Reforms
}

Cara Kaser

Portland State University

Follow this and additional works at: https://pdxscholar.library.pdx.edu/mcnair Let us know how access to this document benefits you.

\section{Recommended Citation}

Kaser, Cara (2004) "The Clerical Wife: Medieval Perceptions of Women During the Eleventh- and Twelfth-Century Church Reforms," PSU McNair Scholars Online Journal: Vol. 1: Iss. 1, Article 4. https://doi.org/10.15760/mcnair.2005.180 
Portland State University McNair Research Journal 2004-2005

The Clerical Wife: Medieval Perceptions of Women During the Eleventh- and Twelfth-Century Church Reforms

by

Cara Kaser

Faculty Mentors:

Caroline Litzenberger and John Ott

Citation: Kaser, Cara. The Clerical Wife: Medieval Perceptions of Women During the Eleventh- and Twelfth-Century Church Reforms. Portland State University McNair Scholars Online Journal, Vol. 1, 2004-2005: 180-212. 


\title{
The Clerical Wife: Medieval Perceptions of Women During the Eleventh- and Twelfth-Century Church Reforms
}

\author{
Cara Kaser \\ Faculty Mentors: Caroline Lizenberger \& John Ott
}

To those who promoted the agendas of the eleventh and twelfth century church reforms the cleric's wife embodied those things which inhibited the process of man reaching the holy: lust, defilement, worldliness, and temptation. But to those who demanded that she remain a part of conventional marital structures and sacred traditions, the clerical wife remained an important - and controversial - aspect of clerical culture throughout the Middle Ages. The figure and image of the priest's wife has eluded historians for generations, as her presence as an important component of the controversy surrounding the heightened enforcement of clerical celibacy throughout the eleventh and twelfth centuries - and beyond - was not prominent in the writings of popes, reformers, or the medieval laity. Perhaps this is why modern historians have not carefully examined the figure of the clerical wife, as ecclesiastical canons, decrees, letters, and vitae sharply point to her regular absence. It is within these absences, silences, and scarce references that the clerical wife is constructed, and it is her absence in these texts that speak strongly to her position as significant in medieval society.

The image of the clerical wife slipped between classifications defined by ecclesiastical traditions and norms, and through the polemical writings of established clergy and church reformers, to become almost non-existent within the scope of medieval history. Her role was not that of the pious laywomen, nor was she a part of the acutely religious culture of monasticism; rather, the life of the clerical wife was intertwined with aspects of holiness and cleanliness, as well as secularity and impurity. The medieval clerical wife embodied the ideal of a "new" religious figure, not set apart from the world of temporality, nor strictly assimilated into the world of the holy, but who instead existed in both, thereby defying conceptions of religious proscriptions that bound medieval women into specific roles and lifestyles. Because of this, the image of the clerical wife remained obscured, as ecclesiastical ideology and negative rhetorical attacks towards women attached to clerical figures peaked during the eleventh and twelfth centuries. The conceptions of clerical wives as motivated seducers, thieves of the Christian faith, and contenders to the traditional, male hierarchy of the church proposed by reformists parlayed into ecclesiastical attempts to enforce clerical chastity, but also met with resistance from clergy and their wives who demanded legalized 
marriages and recognized legitimacy for their children, and who attempted to construct an image of the clerical wife as a beneficial contributor to both clergy and the Christian community.

The clerical wife appeared alongside her husband during the onset of Christianity and remained by his side for almost a millennium after. Growing from humble roots, the clericalconjugal couple eventually faced drastic changes whereby their life-style was condemned and family unit broken, as church authorities attempted to redefine Christianity's own teachings, practices, and theology. Although canons forbidding clerics of certain offices to marry appeared much earlier, ${ }^{1}$ the church reforms of the eleventh and twelfth centuries enforced "a vow of celibacy . . [as] a requirement for ordination to all of the higher positions in the church's clerical hierarchy." 2 These earlier canons demanded sexual abstinence from married clerics once they were ordained, and prohibited priests and other clergy to marry upon entrance to orders. As such, these canons were often merely repeated in later councils. However, the Lateran Council of 1059 pushed a new agenda in an attempt to smother any illicit sexuality of priests, by forbidding anyone to "hear the mass of a priest who, he knows for certain, keeps a concubine or has a woman living with him." ${ }^{3}$ Later in 1074, a Roman council held by Pope Gregory VII stated that married clergy were forbidden to say mass and perform other clerical duties, and that if they refused to obey "the people shall refuse to receive their ministrations, in order that those who disregard the love of God and the dignity of their office may be brought to their senses through feeling the shame of the world and the reproof of the people."4 In later councils, clerics were forbidden to live with any women except "mother, sister, or aunt, or any such person concerning whom no suspicion could arise." ${ }^{5}$ Higher-ranking clergy who retained wives or concubines were to be expelled from their office and cut off from any ecclesiastical benefits, and it was also again decreed, "masses celebrated by members of the clergy who have wives or concubines are not to be attended by anyone." 6

\footnotetext{
${ }^{1}$ The Council of Nicaea held in 325 decreed, "all members of the clergy are forbidden to dwell with any woman, except a mother, sister, or aunt," although it is widely believed that clergy did not really abide by this canon throughout the early Middle Ages, and even during the so-called "Gregorian" church reforms of the eleventh and twelfth centuries. For more information see, "The First Council of Nicaea," 2003, <http://www.newadvent.org/ cathen/11044a.htm> (24 April 2004).

2 James A. Brundage, "Sex and Canon Law," in Handbook of Medieval Sexuality (New York: Garland Publishing, 1996), 36.

3 "The Canons of the Lateran Council of 1059," n.d., <http://lib329.bham.ac.uk/coreRes/papacy/document/ doc_207.htm\#title> (24 April 2004).

4 “Gregory VII: Simony and Celibacy 1074," January 1996, < http://www.fordham.edu/halsall/source/g7reform1.html> (24 April 2004).

5 “The Canons of the First Lateran Council, 1123," November 1996, <http://www.fordham.edu/halsall/ basis/lateran1.html> (24 April 2004). CF the Council of Nicaea in 325.

6 "The Canons of the Second Lateran Council, 1139," November 1996, <http://www.fordham.edu/halsall/
} 
Justification for the noncompliance of the laity to unchaste clergy and even removal of priests or other clerics from office who married, kept concubines, or frequented brothels was rooted in the canonical and biblical doctrine of the church. Correspondingly, the concept of original sin, and therefore the inherent minority status of women, played a crucial role in the depiction of women, and one that had endured for centuries. The description provided by clerical authors of woman as Eve - a temptress - was supported by the notion that a woman "was not a mere pawn, but an active, negative force, a source of disorder in society: she enticed men into the material realm of sin just as Eve had enticed Adam." ${ }^{7}$ Due to this type of rhetoric, women became portrayed as "active" tempters, propelled by their own sexual desire, and were "represented [as] the more physically oriented aspect of human nature, and man . . the more rational aspect." 8 Displays of outward sexual licentiousness and irrationality in public among married women led to an outcry from Guibert of Nogent who exclaimed around the year 1115:

You know, Lord, how difficult, maybe even impossible, it is to find such chastity in women today . . . in their conduct they display nothing but coarse humor . . . their way of dressing couldn't be further removed from old-fashioned simplicity: their broad sleeves, their skintight tunics ... any one of them would imagine she has reached the rock bottom of misery if she is presumed to be without a lover. ${ }^{9}$

In the minds of medieval physicians, support for the belief of women as predominately sexual beings stemmed from notions about sexual desire, such as women desiring sexual intercourse "even when pregnant because their psychological faculties retain the pleasurable effects," 10 the two seed theory and "duplex delectatio," luxuriosa because, no matter how potent the man, her libido cannot be satisfied."12

basis/lateran2.html> (24 April 2004).

${ }^{7}$ Sharon Farmer, "Persuasive Voices: Clerical Images of Medieval Wives," Speculum 61 (1986): 519.

${ }^{8}$ Ibid.

${ }^{9}$ Guibert of Nogent, A Monk's Confession: The Memoirs of Guibert of Nogent, tans, Paul J. Archambault (University Park: Pennsylvania State University Press, 1996), 36.

${ }^{10}$ John W. Baldwin, "Five Discourses on Desire: Sexuality and Gender in Northern France around 1200," Speculum 66 (1991): 805.

${ }^{11}$ Baldwin, 818. The theory of duplex delectatio ("double pleasure") suggested that while "the man knows only one pleasure in emitting seed, the woman experiences a duplex delectatio in both the emission of her own seed and the reception of the male's," as medieval doctors believed women emitted their own "seed" during sexual intercourse.

${ }^{12}$ Ibid. 
This perceptibly unsatisfiable sexual appetite of women, especially in regards to priests' wives, provided problems for ecclesiastical authorities who not only consistently tried to regulate the sexual behaviors of the lay population, but who now also tried to regulate and enforce the celibate and spiritually pure state of clergy members. Dyan Elliot asserts "the establishment of clerical celibacy as a mark of both difference and superiority was central to [the reform] ... [and] these ends were, in part, achieved by a remarkable spate of pollution-laden rhetoric unequaled in the previous history of the western church." 13 Ordering clergy to obey canons and decrees against marriage, concubinage, and fornication only went so far in enforcing the ideals of church authorities. But by attacking clerical wives as disgraces and polluters of both the clerical person and office, reformers were able to confront misbehaving clergy from a new platform. The classic characterization of femininity encompassing only two models - the Virgin Mary and Eve - provided ample material to criticize clerical wives, since these women embodied neither the characteristics of Mary nor Eve:

the animals perceived as abominations in the Book of Leviticus are precisely those creatures that transgress against apprehended divisions among species: things that live in the sea, but crawl; animals with cloven feet that refuse to chew their cud like the "clean" animals of the flock. The priest's wife is a vivid representation of this kind of anomaly - numerically squared and historically writ large - precisely because her mixed, hybrid, "impossible" status is ambiguous in a way that reveals the seams in classificatory categories. At a time when reformers were insisting on a strict division between clergy and laity, she defies both categories .... ${ }^{14}$

But how many clerics actually believed in the Mary-Eve dichotomy? And how far reaching were celibacy laws and to what extent were these laws actually enforced? Ideologically, the most powerful way in which church authorities could enact a reform agenda was through ecclesiastical legislation, particularly legislation that was practical and could be physically enforced. The canon that allowed the boycotting of priests who married or kept women in their household who could cause suspicion, declared under Pope Nicholas II in 1059, enabled a practical solution to clergy who did not abide to earlier decrees designed to end clerical marriage and concubinage. But by far one

${ }^{13}$ Dyan Elliot, Fallen Bodies: Pollution, Sexuality, and Demonology in the Middle Ages (Philadelphia: University of Pennsylvania Press, 1999), 82.

${ }^{14}$ Elliot, Fallen Bodies, 83. 
of the most widely, although not altogether persuasive, tools reformers utilized was correspondence in the form of letters between clerics of all ordinations. "Letters in the classical and medieval worlds were neither strictly private communications nor public writings," 15 therefore, letters were potentially read out loud to the recipient or perhaps to a group of people as was the case of Gregory VII who wrote to the clergy and laity of the diocese of Constance in late 1075 about the lack of enforcement in regards to simony and clerical celibacy on the part of Bishop Otto, and insisted:

by apostolic authority we charge all of you, both greater and lesser, who stand by God and St. Peter, that if he [Otto] is determined to continue in his obduracy you should show him neither respect nor obedience ... For if, as we have often said already, he is determined to resist apostolic precepts, we so absolve you by St. Peter's authority from every yoke of subjection to him that, even if any of you is bound to him by the obligation of an oath, for so long as he is a rebel against God and the apostolic see you are bound to pay him no fealty. ${ }^{16}$

Gregory VII strove to parlay his letter into restructuring social relationships between by parishioners and clergy in a specific diocese. Registers, histories, and other writings not only captured the correspondence of those who sought to enforce clerical chastity, but also captured the opinions, and, in some instances, blatant attitudes and actions of those who resisted against these changes. Episodes of physical aggression undertaken by bishops or archbishops in attempts to enforce celibacy legislation also were recorded in some medieval sources. One such incident involved the archbishop of Rouen, Geoffrey, who in 1119 upon his return from a council in Reims, gathered his clergy together and declared that all must cease living with women, and also sever relations with their wives and children under penalty of excommunication. ${ }^{17}$ The clergy of Rouen, however, complained to the archbishop and refused to accept papal legislation regarding clerical celibacy. In retaliation for their disobedience, an "outspoken rebel"18 cleric named Albert the Eloquent was imprisoned without any charge of crime and without any kind of legal preceding. Dumbfounded,

\footnotetext{
${ }^{15}$ Robert of Arbrissel, Robert of Arbrissel: A Medieval Religious Life, trans. Bruce L. Venarde (Washington, D.C.: The Catholic University of America Press, 2003), 89. 1972), 25.

${ }^{16}$ H.E.J. Cowdrey, ed. and trans, The Epistolae Vagantes of Pope Gregory VII (Oxford: Clarendon Press,

${ }^{17}$ Anne Llewellyn Barstow, Married Priests and the Reforming Papacy: The Eleventh Century Debates (New York: The Edwin Mellen Press, 1982), 95.

${ }^{18}$ Ibid.
} 
the priests prepared to defend themselves, lest they be taken away as well. In response, Orderic Vitalis wrote that Geoffrey sent in armed retainers who:

rushed straight into the church with staffs and weapons and began to lay about them irreverently in the throng of clergy who were talking together. Some of the clergy, still clad in their albs, rushed through the muddy lanes of the city to their lodgings; others, however, snatching up any staffs or stones they happened to find there tried to fight back and, driving the wavering guard right back to the archbishop's private apartment, pursued them violently. The retainers, ashamed at having fled defeated before a band of unarmed clergy, grew angry and immediately enlisted the help of the cooks and bakers and attendants who were at hand, and retaliated by sacrilegiously renewing battle in the holy sanctuary. They struck or jostled or injured in some other way all, innocent or guilty, whom they could find in church and cemetery. $^{19}$

Orderic also reported that while this violence went on:

some other mature and pious old priests were waiting in the consecrated building ... the crazy servants [the recruited laymen] rushed at them blindly, heaped abuse on them and only at the last moment restrained their hands from slaughter because the priests fell on their knees weeping and begged for mercy. The moment they were released they fled as fast as possible from the city ... [and] carry[ed] back alarming reports to their parishioners and concubines, and showing the wounds and livid bruises on their bodies as proof of their words. $^{20}$

Physical enforcement of clerical celibacy was but one tactic ecclesiastical authorities used to implement reform, ${ }^{21}$ as other letters abound in this period regarding additional measures. The archbishop Lanfranc of Canterbury wrote that proper penance for a priest should include

${ }^{19}$ Orderic Vitalis, The Ecclesiastical History, ed. and trans. by Marjorie Chibnall (Oxford: Clarendon Press, 1972), 6:293.

${ }^{20}$ Ibid.

${ }^{21}$ Although physical expressions of disapproval and defiance on the part of clerics often turned violent in specific and concentrated areas of northwestern Europe. See James A. Brundage, Law, Sex, and Christian Society in Medieval Europe (Chicago: University of Chicago Press, 1987), 220-221; Orderic Vitalis, Ecclesiastical History, 2:200. 
maintaining a celibate state, ${ }^{22}$ that a married man improperly ordained a deacon be stripped of office, $^{23}$ and also wrote in support of a fellow archbishop who was at odds with his own archbishopric. ${ }^{24}$ Many letters strongly address proper conduct and punishments for priests, provide answers to questions posed by other clerics, and suggestions for handling volatile situations.

Attempts to encourage priests and other clerics to chastity proved easier to decree than to actually enforce. Admonishments from archbishops, bishops, and secular rulers urged reformers not to waver in implementing reform legislation among their clergy, such as Duke William of Normandy in 1080 who "criticized his bishops for not enforcing celibacy and warned that they must cease collecting cullagium, the 'tax' married priests were forced to pay in order to live with their wives." 25 However, reservations about enforcing church legislation on the part of clerical authorities and proponents of reform were not unfounded. Again in the archbishopric of Rouen, Archbishop John (d. 1079) "led a merciless campaign against vice ... For ten years he fulfilled his duties as metropolitan with courage and thoroughness, continuously striving to separate immoral priests from their mistresses."26 However, when John attempted to enforce canons from the 1064 Council of Lisieux dealing with clerical marriage and concubinage during the Council of Rouen in 1072, he was stoned by his clergy. ${ }^{27}$ In 1074, "when the Bishop [Josfried] of Paris told his priests that they must give up their wives and children, they drove him from the church with jeers and blows, and he found it necessary to take refuge with the royal family in order to escape the wrath of his outraged clerics." $^{28}$ And in 1077, Bishop Josfried learned from Gregory VII that "the citizens of Cambrai have delivered a man to the flames because he had ventured to say that simoniacs and fornicating priests ought not to celebrate masses and that their ministration ought in no way to be accepted." ${ }^{29}$

Other protests and demonstrations against clerical celibacy were not only led by and acted out by clergy, but also by their wives and other supporters. According to his vita composed some time after 1131, while in Normandy around the first quarter of the twelfth century, Bernard of Tiron preached to an assembly of priests not to marry or fornicate with their wives. However, fearing

${ }^{22}$ Lanfranc Archbishop of Canterbury, The Letters of Lanfranc Archbishop of Canterbury, ed. and trans. Helen Clover and Margaret Gibson (Oxford: Clarendon Press, 1979), 109.

${ }^{23}$ Ibid, 139.

${ }^{24}$ Ibid, 135.

${ }^{25}$ Barstow, 88-89.

${ }^{26}$ Orderic Vitalis, 2:200.; see especially note 5.

${ }^{27}$ Ibid.

${ }^{28}$ Brundage, Law, Sex, and Christian Society, 221. Bishop Josfried was the chancellor of King Philip I.

${ }^{29}$ H.E.J. Cowdrey, The Register of Pope Gregory VII, 1075-1085: An English Translation (Oxford: Oxford University Press, 2002), 231. 
separation from their husbands, the priest's wives gathered with "their allies to thwart him," 30 and the priests also planned to ambush Bernard in order to stop his preaching.

If while physical violence and bloodshed were extreme outcomes from an outraged clergy, others expressed their frustration through letters and other writings, such as poems:

Priests who lack a girl to cherish

Won't be mindful lest they perish.

They will take whom'er they find

Married, single - never mind! $!^{31}$

Written shortly after the Fourth Lateran Council in 1215 - well over a century after the "Gregorian reforms" of the late eleventh century - an anonymous poet laments the future priests, who, he predicts, will commit fornication and adultery at a higher rate than their predecessors because of the denouncement and illegal standing of clerical marriage. The tone of the anonymous poet reverberated with earlier authors and critics. The Anonymous of York explained that defining marriage as illegal for clerics would propel unchaste clerics to commit more serious crimes. He reasoned:

The apostle laid it down that "a bishop should be the husband of one wife." He would hardly have made this ruling . . . if it were adultery, as some assert, for a bishop to have at one time both a wife and a church - two wives, so to speak ... For Holy Church is not the priest's wife, not his bride, but Christ's. ${ }^{32}$

Bishop Ulric of Imola wrote to Pope Nicholas II in 1060 explaining that when clerics are not allowed to marry “[they] do not hesitate to make use of other men's wives (we weep to tell it), and rage in unspeakable evils." 33 He also defended clerical marriage as biblically legal, using the same

${ }^{30}$ Geoffrey the Fat, Vita beati Bernardi fundatoris congregationis de Tironio in Gallia, PL 172 (Paris, 1854).

${ }^{31}$ Brundage, Law, Sex, and Christian Society, 402.

${ }^{32}$ C.N.L. Brooke, "Gregorian Reform in Action: Clerical Marriage in England, 1050-1200," Cambridge Historical Journal 12 (1956): 14.

${ }^{33}$ Barstow, 111. Historians differ on whether the Rescript of Bishop Ulric was written by Bishop Ulric of Imola (1053-1063) or Bishop Ulric of Augsburg (d. 973). See Barstow, 234 n.2, and Brundage, Law, Sex, and Christian Society, 221 n.236. 
passages that proponents of clerical celibacy often used in their own writings. Ulric insisted that these passages' original words and interpretations were twisted by reformers for their own ends, especially 1 Corinthians 7:2 ("But because of the temptation to immorality, each man should have his own wife and each woman her own husband") in which the word laicus was inserted into the text at the Council of Chelsea in 787 , thus narrowing the interpretation. ${ }^{34}$ Frustrated, Ulric defended clerical marriage with what he considered original scripture and insisted, "these [reformers], no doubt, have not rightly understood scripture, since they have pressed its breast so hard that they have drunk blood in place of milk." ${ }^{35}$

The defense of clerical marriage based on scriptural evidence, as put forth by Ulric, was not the attitude of only one individual. Many critics of reformers' attempts to separate priests and clerics from their wives and children used the argument that clerical marriage was sanctioned by scripture as well as tradition. Even though canons passed much earlier declared, for example, that a cleric could legally have only one wife, and those who lived in religious communities could not marry ${ }^{36}$, only during later church reforms was clerical celibacy strictly imposed upon priests, bishops, and other clerics.

The conception of chastity as the desired state for a clergyman was part of a growing trend across Europe beginning in the Early Middle Ages and through the Late Middle Ages that continuously emphasized the special and elevated status of clergy over the laity. "There was no sudden break with the earlier custom of married clergy, but instead a gradual accumulation of rulings sacralizing the clergy," 37 which transformed the role of the priest from a man among the laity, to a man apart from the laity, who was socialized to recognize the importance of his specific and sacred purpose. Thus, "the old ideas of a pastoral ministry, of voluntary chastity, [and] of an intermingling of sacred and secular values in the sacraments were challenged." 38

Sacerdotal ministry began to outweigh pastoral ministry as the image of the medieval priest changed from that of quasi-layman to exclusive mediator between God and man. In lieu of this new social standing, ecclesiastical authorities proposed that because priests provided such a sacred part of Christian ritual, priests should therefore not dabble in banal lay behavior. Instead, the priest should

34 Ibid.

35 Ibid. "The Rescript of Bishop Ulric was formally condemned by the Synod of Rome in 1079, and the arguments of other adversaries of the celibacy rule were either ignored or dismissed as irrelevant by the reforming party." Brundage, Law, Sex, and Christian Society, 221-222.

${ }^{36}$ Brundage, "Sex and Canons Law," 36.

37 Barstow, 23.

38 Barstow, 29. 
be recognized among other men as purified from sin, and living in a state that is acceptable to God, who, theologically, ministered through the spirit and body of the priest.

This growing notion of ritual and purity prompted church officials to reconsider earlier decrees that stated that married priests could legally be ordained, but once ordained had to refrain from sexual intercourse with their wives. ${ }^{39}$ Instead, stricter legislation surrounding the sexual practices of clergy continued to evolve throughout the tenth, eleventh, and twelfth centuries. "This new asceticism created innumerable personal crises, not only for priests and other clerics, but also for their wives, children, families, and parishioners. Reformers demanded that married clergymen eject wives and children from their homes and embrace a life of celibacy unencumbered by carnal temptations and the distractions of family life." 40

In order for clergy to fully embrace a sinless life, church authorities saw it necessary to cut off clergy from their secular families - thus dissolving relations with the priest's wife, and keeping the priest free from defilement from sexual intercourse. According to reformers, association and sexual encounters with women not only affected a priest personally, but also affected his relationship with God, and therefore God's relationship with a priest's community of believers. The reformer Peter Damian wrote pointedly to fornicating priests, "What business have you to handle the body of Christ, when by wallowing in the allurements of the flesh you have become a member of antichrist? ... Since you burn with this passionate desire, how can you be so bold, how can you dare approach the sacred altar?" 41 Thus, reformers asserted that the "tainted" sacrament resulted in a chain reaction of problems that placed the salvation of everyone who received the host from the hands of a fornicating priest in peril. Therefore, the restrictions imposed by such popes as Nicholas II and Gregory VII against taking communion from priests who were known fornicators were necessary in the eyes of the church to prevent the spiritual slaughter of innocent, and perhaps unknowing Christians. And women who consorted sexually with clerics only added to the carnage, as "the most frequently avowed reason for suppressing the clerical wife was that her sexual presence polluted the minister of the altar," ${ }^{42}$ and therefore soiled the sacredness of the priest's body, office, and flock. Caesarius of Heisterbach recounted the story of a priest named Adolph who, when

${ }^{39}$ Paul Beaudette, "In the World But Not of It": Clerical Celibacy as a Symbol of the Medieval Church," in Medieval Purity and Piety: Essays on Medieval Clerical Celibacy and Religious Reform, (New York: Garland Publishing, 1998), 27.

${ }^{40}$ Brundage, "Sex and Canon Law," 36.

${ }^{41}$ Peter Damian, "Letters 31-60," in The Fathers of the Church, trans. Owen J. Blum (Washington, D.C.: Catholic University of America Press, 1989), 10-11.

${ }^{42}$ Elliot, Fallen Bodies, 83. 
celebrating mass, was shocked to see visions of a nursing Mary, a lamb, and the crucified Christ in the elevated host. "When he saw this, the priest was terrified and stood for a long time thinking whether he ought to stop there, or finish the office ... and when the congregation wondered at the delay, he went up into the pulpit and told the people the vision with many tears." ${ }^{43}$ Ceasarius comments, "And I do not wonder that [he] was not able to look upon Him so clearly and so joyfully whom he daily sacrificed and received to his own condemnation. For he lived with a concubine."

Fear of women's sexuality, or women's “polluted” bodies, was only one position offered by polemists as to why women should not marry nor engage sexually with clergy. The idea of physical, gendered space between women and church property and women and clergy, poses an interesting perspective on the perceived role or intentions of the cleric's wife. Jane Tibbetts Schulenburg proposes, "the adoption of gender based spatial proscriptions can be seen as an indirect index of ecclesiastical authority over women: they embody underlying values/attitudes and fears of the church hierarchy towards female sexuality and the perceived disruptive nature and 'uncontainability' of women." Damian spoke directly to these fears of a spiritual and social disruption through his personification of women as enemies, waiting for opportune times to launch attacks, and also as stinging and biting insects or beasts who inject venom and painfully murder their victims - the bodies and spirits of clergymen. ${ }^{46}$ However, reformers not only spoke to fears regarding the pure state of clergy, but also to the pure and healthy state of the entire church body - the community of Christian believers, the body of Christ. According to Amy G. Remensynder, the actions of unchaste priests endangered the "peace which bound Christians together to form one mystical-social body, one church. This peace was engendered by the bonds of charity between human beings." ${ }^{47}$ Since peace made up the essence of Christian bonds, priests' wives disrupted this peace, and therefore could figuratively topple the body of Christ.

However, reformers also pointed to the fact that the body could not topple all at once, but that the impurity of the women who enticed clerics acted as a sickness that slowly infected the head,

43 Caesarius of Heisterbach, The Dialogue on Miracles, trans. H. von E. Scott and C.C. Swinton Bland (New York: Harcourt, Brace and Company, 1929), 2:110.

${ }^{4}$ Ibid.

45 Jane Tibbetts Schulenburg, "Gender, Celibacy, and Proscriptions of Sacred Space: Symbol and Practice," in Medieval Purity and Piety: Essays on Medieval Clerical Celibacy and Religious Reform (New York: Garland Publishing, Inc., 1998), 354.

${ }^{46}$ Elliot, Fallen Bodies, 102.

47 Amy G. Remensnyder, "Pollution, Purity and Peace: An Aspect of Social Reform between the Late Tenth Century and 1076," in The Peace of God: Social Violence and Religious Response in France around the Year 1000 (Ithaca: Cornell University Press, 1992), 294. 
limbs, and eventually the whole body. Again, Peter Damian described the situation, using epidemiological terms, as an "epidemic," 48 and insisted, "this disease is spreading like a cancer, and its poisonous breed will reach out endlessly unless its evil growth is cut off by the scythe of the gospel," ${ }^{49}$ and also charged "through [these women], therefore, the devil devours his elect food, while he tears the very holy members of the church with his teeth . . . and when he joins [the priests] to [their sexual partners], he transposes [the priests] into his own guts as it were transferring them." ${ }^{50}$ Therefore, women's sexuality acted as a conduit for evil to snatch away the sacredness of Christianity, in essence "a kind of rape of the altar in the doubling meaning of the word rapier - a sexual crime against the animate offering to God, the priest; and a theft perpetrated against the Christian community at large." 51

However, as mentioned before, many priests and clerics refused to accept these new legislations and perceptions of women, which they saw as contrary to scriptural law and cultural tradition. Instead, some clerics began to advocate for the church to recognize the validity of their marriages, as well as legitimacy for their children. Priests and clerics reasoned that if they could not legally participate in matrimony, that clerics would indulge in other, more serious elicit activities.

This fear would seem to be borne out in French fabliaux from the twelfth and earlier thirteenth centuries recounted many stories of lewd and lustful priests who actively looked for sexual encounters. In the tale of Estormi, three lusty priests individually offered a woman, who had fallen into extreme poverty, money in exchange for sexual favors. Having told her husband, together the woman and man scheme to murder the priests individually but to profit financially from the clerics' sexual appetite. Each of the three deceived priests came over to the woman's house at different times, each giving the woman money, but just as they were expecting to receive their requests, the woman's husband killed each one with a cudgel. ${ }^{52}$ Another fabliau entitled Aloul, related the adventures of a lewd priest who wooed a beautiful woman who was resentful of her suspicious husband. Tired of her situation, the woman went out to her orchard early one morning where she encountered her neighboring priest who cunningly devised a way to have sex with her, and thus, to become her lover. ${ }^{53}$ Other fabliaux tell of a priest who is castrated for seducing the wife of a crucifix

\footnotetext{
${ }^{48}$ Damian, 4.
}

${ }^{49}$ Damian, 12.

${ }^{50}$ Elliot, Fallen Bodies, 102.

${ }^{51}$ Elliot, Fallen Bodies, 102-103.

${ }^{52}$ Raymond Eichman and John DuVal, eds. and trans., The French Fabliau: B.N. MS. 837 (New York: Garland Publishing, 1984), 1:3-27.

${ }^{53}$ Ibid, 1:165-167. 
craftsman $^{54}$, a priest who hates the laity, is greedy, and keeps a wife ${ }^{55}$, and a priest who "preys on his parishioners" 56 for his own sexual pleasure.

In The Priest Who Peeked, the parish priest is in love with his parishioner's wife and goes to her house to tell her. Peering through a hole in the front door, the priest sees that the man is eating dinner with his wife. However, the priest convinces the peasant man that he does not see him eating dinner, but instead having sex with his wife. The peasant refuses these accusations, and invites the priest inside to eat. However, the priest persuades the peasant to trade him places so that the peasant can see what he saw through the door. Agreeing to this, the peasant goes outside and looks through the hole in the door, only to see the priest raping his wife:

"May God Almighty help you, Sir,"

The peasant called, "Is this a joke?"

The parson turned his head and spoke:

“No, I'm not joking. What's the matter?

Don't you see: I have your platter.

I'm eating supper at your table."

"Lord, this is like a dream or fable.

If I weren't hearing it from you,

I never would believe it true

That you aren't [having sex] with my wife."

"I'm not, Sir! Hush! As God's my life,

That's what I thought I saw you do."

The peasant said, "I guess that's true." 57

\footnotetext{
${ }^{54}$ Raymond Eichman and John DuVal, eds. and trans., The French Fabliau: B.N. MS. 837 (New York: Garland Publishing, 1984), 2:63-67.

55 John DuVal, trans., Cuckolds, Clerics, \& Countrymen: Medieval French Fabliaux (Fayetteville: University of Arkansas Press, 1982), 15-28.

56 Ibid, 7.

${ }^{57}$ Ibid, 46. The original French provided by the translator is as follows: Et quist chou: "Se Dix vous sequeure,"/Fait li villains, "est che à gas?"/Et li prestres en eslepas/Respont: "Que vous en est avis?/Ne veés vous? Je sui assis/Pour mangier chi à ceste table."/“Par le cuer Dieu, ce samble fable,"/Dist li villains, "ja nel creise,/S'anchois dire nel vous oisce,/Que vous ne foutissiés ma femme."/"Non fach, sire, taisiés; par m'ame,/Austrestel sambloit ore à moi."/Dist li villains: "Bien vous en croi."
} 
The audience's reaction to fabliaux depicting priests as unattached, seducing men most likely "would have been one both of recognition and of shock on hearing of priestly actions totally out of keeping with priestly ideals." 58 The overt anti-clericalism of the fabliaux is interesting in that of a survey of fifty-six tales involving priests, only four treat the priest favorably:

Clearly the ecclesiastics enjoyed the least favor among the fabliaux authors ... [perhaps] due to the authors' resentment at harsh treatment of assumed heretics in northern France during the thirteenth century by church officials ... such a view would, of course, imply that the fabliaux are more than entertainment and that they satirize with the intent of reforming abusive conditions. ${ }^{59}$

But why were priests satirized in this manner? Since the majority of priests depicted in the fabliaux were described as lustful, unattached, and greedy, was this a sign of disapproval among the laity of the church's handling of clerical sexuality? Did eleventh- and twelfth-century laymen and women share the same reaction as their fifteenth-century counterparts in Switzerland and some areas of Spain who insisted that their priests marry, "“as a safeguard for the virtue of their wives and daughters and as a remedy for the flagitious lives of priests and prelates?" biographer that Bernard of Tiron preached against married and fornicating priests during the twelfth century "with the people cheering him on," 61 while in a poem by Matthew of Vendôme, a lady declared she would rather give herself to a knight than a cleric, because she did not want to sleep around, but wanted to get married, thereby recognizing that "a cleric could do the one, but not the other." 62

However, accounts of priests' wives, concubines, and families still made their way into medieval records, meaning that, "it was easier to mandate clerical celibacy than it was to turn off basic human drives." ${ }^{\prime 3}$ Clerical marriage was far from dead even though reformers zealously hoped for its demise, and priests continued to either marry, or procreate with women in their households whom they considered legitimate marriage partners. For example, the Flemish bishop, Henry of

\footnotetext{
58 Ibid, 7.

${ }^{59}$ Ibid, 8.

${ }^{60}$ Ibid, 7.

${ }^{61}$ Geoffrey the Fat, Vita beati Bernardi fundatoris congregationis de Tironio in Gallia, trans. J.S. Ott, PL 172. 1363-1446.

${ }^{62}$ Brundage, Law, Sex, and Christian Society, 222.

${ }^{63}$ James A. Brundage, "Sin, Crime, and the Pleasures of the Flesh: The Medieval Church Judges Sexual Offences," in The Medieval World (London: Routledge, 2001), 298.
} 
Gelders, "openly bragged of his sexual prowess and claimed to have sired fourteen sons in twentytwo months" ${ }^{64}$ However, reformers continued to condemn these acts and also sought an attack on the sexual act itself between clergy and women, equating sexual intercourse with incest. Peter Damian admonished:

Cleary, if a father incestuously seduces his daughter, he will be promptly excommunicated, forbidden communion, and either sent to prison or exiled. How much worse, therefore, should be your degradation, since you had no fear of perishing with your daughter, not indeed in the flesh, which would be bad enough, but rather with your spiritual daughter? . . since you are the husband, the spouse of your church, symbolized by the ring of your betrothal and the staff of your mandate, all who are reborn in her by the sacrament of baptism must be ascribed to you as your children. Therefore, if you commit incest with your spiritual daughter, how in good conscience do you dare perform the mystery of the Lord's body? ${ }^{65}$

Therefore, clergy and their wives or concubines were not only committing crimes against the Christian church, but were also committing crimes against nature, by perverting the instinctual (and spiritual) bond between father and daughter. Elsewhere in his writings, Damian also quoted the book of Matthew ("For an evil tree cannot bear good fruit" ${ }^{\text {"66) }}$ ) to describe the undesirable outcomes (i.e., offspring) of incestuous breeding.

Growing concern regarding the offspring of clerics also worried reformers and ecclesiastical authorities. Many authors insisted that clerics should divorce their wives and sever ties with their concubines, prostitutes, lovers, and children, while others advocated that the church should enslave the ex-wives of clerics as well as their children. ${ }^{67}$ Although clerics more than likely considered the children they fathered legitimate, church reformers and authorities moved quickly to stem these presumptions. The council of Bourges in 1031 created two canons which "prohibited the entrance into orders of any son of a cleric ... Here children of the clergy were assimilated not only to servi

\footnotetext{
${ }^{64}$ Brundage, "Sin, Crime, and The Pleasures of the Flesh," 299.

${ }^{65}$ Damian, 10.

${ }^{66}$ Damian, 398.

${ }^{67}$ Brundage, "Sin, Crime, and The Pleasures of the Flesh," 299.
} 
and coliberti but to all children not born from a 'legitimate union' who 'are called cursed seed in the Scriptures and who, according to secular law, can neither inherit nor give legal testimony.”,68

But why were reformers so concerned about the children of clerics? Canon 16 of the Second Lateran Council stated:

It is beyond doubt that ecclesiastical honors are bestowed not in consideration of blood relationship but of merit ... Wherefore, in virtue of our Apostolic authority we forbid that anyone appropriate or presume to demand on the plea of hereditary right churches, prebends, deaneries, chaplaincies, or any ecclesiastical offices. ${ }^{69}$

The overlying intentions of church authorities were clear. Sons of clerics had undoubtedly at one point or another claimed hereditary rights to ecclesiastical lands, offices, or other benefits, and some clerical fathers, more than likely, either granted or tried to grant these claims. "Sacerdotal dynasties were common, almost the norm, in some regions of eleventh-century Europe, and had been commonplace for centuries." ${ }^{, 70}$ However, ecclesiastical authorities did not want Christendom carved up and, in essence, "ruled" by hereditary lines of churchmen, nor did the church want to lose land and money to dynastic clerical families. ${ }^{71}$

The uneasiness of church officials towards clerical children was also attributed to the fact that clerics, especially those who were married, had to support their families. Therefore tithes or other gifts given to local priests or clerics could potentially end up in the mouths and stomachs of clerical offspring, instead of in the coffers of local parishes or sees. Because of this, "married clergy were considered to plunder the church" 72 as "these bishops "were not pastors, but instead mercenaries (John 1:12-13), who were not watching over the bodies of their sheep, but were taking their wool and sucking their milk (Ezek. 34:2-3) and were seeking their own gain and not that of

\footnotetext{
${ }^{68}$ Remensnyder, 288.

69 “The Canons of the Second Lateran Council, 1139," November 1996, <http://www.fordham.edu/halsall/ basis/lateran2.html> (24 April 2004).

${ }^{70}$ Brundage, Law, Sex, and Christian Society, 215.

71 “The Canons of the Second Lateran Council, 1139," November 1996, <http://www.fordham.edu/halsall/ basis/lateran2.html> (24 April 2004). "Owing to the license and venality of the times, episcopal sees were frequently usurped and given as fiefs to soldiers in recompense for services. Once in such hands, they were treated as property which descended by hereditary right from father to son. Likewise many of the clergy, bishops and priests, who had taken wives and begotten children, transmitted their benefices to their offspring."

${ }^{72}$ Remensnyder, 293.
} 
Jesus Christ." ${ }^{, 73}$ How did this effect the view of the local Christian community who faithfully gave tithes, alms, and gifts to the church, but which were diverted to sustain a priest's family? ${ }^{74}$

Even though canons and ecclesiastical laws decreed by church authorities directly influenced the decisions and rights of clerical offspring, they also affected the influences of the mothers of these children. Therefore, by stemming the rights of clerical offspring, church authorities were also stemming the influences of women involved with clergy, because these children, born out of unlawful, condemned relationships between women and clergy, directly contested the authority of church hierarchy. Hence, children of clergy were products of disobedient servants to the church, as "ecclesiastical definitions of valid sexual activity shaped the medieval definition of illegitimacy." 75 In essence, "illegitimacy was thus used as a lever to define valid marriage,"76 and because the marriage between a woman and priest would never be considered valid, illegitimacy, therefore, was "a public manifestation of the parents' immorality ... [and] represented forbidden sexual intercourse."77

Because children of clerics represented pollution, opposition to church order, and immorality among the clergy, the condemnation of sexual contact between women and clergy solidified even more. Sexual contact with women not only resulted in the pollution of the altar, and possibly the whole church body, but also in illicit sexual unions producing illegitimate children, and also turned the attention of the minister away from his flock to instead gaze upon his prohibited wife and unlawful children. Thus, sexual association with women produced an "illegitimate, soft, [and] effeminate lot, degenerating from the genuine nobility of the order of priests"78 - a feminization of the clergy that upset the traditional male hierarchy of the church. This seems to be confirmed by writings such as the vita of Geoffrey of Amiens, a reforming cleric who foiled a clerical concubine's attempt to poison him, who is described in very masculine terms. The author describes how Geoffrey, "manfully barred disreputable clergy fornicating in impure matrimony not only from his company but also from entering the choir," how he "persisted through everything with the spirit of manly steadfastness," and "battled against the devil and his agents.,"79

\footnotetext{
${ }^{73}$ Remensnyder, 290.

${ }^{74}$ R.I. Moore, "Family, Community and Cult on the Eve of the Gregorian Reform," Transactions of the Royal Historical Society 30 (1980): 62.

${ }^{75}$ Laura A. Wertheimer, "The Ecclesiastical Construction of Illegitimacy in the Middle Ages” (Ph.D. diss., University of California, Santa Barbara, 2000), 63.

${ }^{76}$ Ibid, 78.

${ }^{77}$ Ibid, 104-105.

${ }^{78}$ Elliot, Fallen Bodies, 105.

${ }^{79}$ Vita sancti Godefridi auctore Nicolao monacho Suessionensi, ed. Albert Poncelet, Acta sanctorum novembris, collecta digesta illustrata, vol. 3 (66) Brussels: Socios Bollandianos, 1910, pp. 905-44.
} 
In the eyes of church authorities, an effeminate clergy also meant a decline in pastoral and spiritual "fatherly" duties. Peter Damian urged clerics symbolically to "marry a priestly wife from whom he might procreate offspring who will reflect their father's character," "marriage" to the church, and also chastised clerics who were spiritually impotent.

But if God so hates sterility in the brute beasts which are offered to him through the ministry of priests, how much more does he disdain it in the priests who offer sacrifice to him? Surely just as offspring in the flesh are required of [the beasts], so priests should propagate holiness in others. Only then will your chastity be approved in the divine gaze, if it is extended by propagation among your clerics. ${ }^{81}$

According to Damian, in taking wives or lovers and begetting children, priests and other clerics undermined the spiritual well being of their communities. "The role of spiritual father entailed many of the same obligations as that of a secular father;" ${ }^{2}$ however if these roles were not fulfilled then the proper ordering of society was also overturned, as these spiritual "fathers" were neglecting their acknowledged parental roles. The expectation for clerics to act as spiritual fathers towards their flock was undercut by cleric's involvement with women, and although women may not have been directly responsible for the malnourishment of parishioners and other faithful Christians, church officials saw clerical wives as tools that aided the offenses of clerics. Women added carnality and distraction from the realm of the holy and divine, to the world of temporality, where the attention and energy of a priest was transposed from the spiritual concerns of laymen to the immediate physical concerns of his wife or lover and his family. Reformers' propaganda explained how priests' wives and concubines were decorated with jewels and luxurious and ornamented clothing, while the altar was left without jewels and bare, and the priest himself walked about wearing rags for clothes in order to support his wife's expensive tastes. ${ }^{83}$

Priests, bishops, and other clerics' "open relations with women (uxorati publicae) were public offenses and represented an inversion and perversion of the reverence laymen had for religious

\footnotetext{
${ }^{80}$ Damian, 398.

${ }^{81}$ Megan McLaughlin, "Secular and Spiritual Fatherhood in the Eleventh Century," in Conflicted Identities and Multiple Masculinities: Men in the Medieval West (New York: Garland Publishing, 1999), 29.

${ }^{82}$ McLaughlin, 31.

${ }^{83}$ Elliot, Fallen Bodies, 121.
} 
women - a turning inside out of proper relations between men and women, clergy and laity." 84 In other words, clerics acted like laymen, in that they married or were sexually active, produced children from these relationships, and needed or wanted to support their family:

Many of those who are in bondage to the delights of carnal pleasure long to perpetuate their own memory through their posterity. This they pursue through every waking moment, since they are sure that they will not be wholly dead in this world if they continue their name in a fruitfully surviving progeny. ${ }^{85}$

Whether or not a cleric's sexual drive was fueled by desires of perpetual life sustained by later generations, sexually promiscuous clergy "contradicted their ordo - and the order of the world." 86 "Disruptores, violators, and raptores - from the sixth century onward . . were the terms employed in narrative sources and conciliar canons to brand those who perturbed the 'peace of the church' ... [and, among others,] impure clerics were considered to be violators . . just as were laypeople who infringed any of the peace regulations." 87 The blurred lines between what was holy and divinely ordered and what was secular and man-made exacted pressures on ecclesiastical authorities to retain traditional societal structures. According to Sharon Farmer, "both scholastic and monastic authors [around the year 1200] began to recognize the moral and spiritual potential of women's persuasion." 88 Although Farmer writes about this persuasiveness in regards to lay women who had the ability to sway their husbands' decisions regarding donations to monasteries and other church benefices, perhaps this theory can also describe the relationships between clerics and their wives:

.. . writers persistently emphasized the ability of women to use spoken language - sweet words and eloquence - to soften men's hearts ... in their use of speech and sexual enticements to manipulate men the pious wives of the eleventh-, twelfth-, and earlythirteenth-century sources resemble contemporary depictions of Eve, who compelled Adam "to obey her voice rather than the Word of God" ... Woman is "garrulous" and "induces

\footnotetext{
${ }^{84}$ Remensnyder, 290.

${ }^{85}$ McLaughlin, 28.

${ }^{86}$ Remensnyder, 290.

${ }^{87}$ Remensnyder, 292.

${ }^{88}$ Farmer, 521.
} 
crime with her . . voice and hand." Moreover, her tongue is more flexible - "more mobile and given to words" - than is that of the male and it "can be seen to be the seedbed of all evil." $" 89$

Reformers undoubtedly expressed similar concerns about clerical wives. If a wife possessed the innate ability to sway her lay husband with speech and gestures, how much more could a wife of a priest or other cleric influence her husband who exercised certain responsibilities and privileges within the community at large?

Clerical wives had traditionally remained within the community, even though eleventh and twelfth century reformers wrote with an obvious agenda to categorize women as potentially evil beings, as their ends were targeted at male clerical chastity, and to limit the influence women had in the church through the lives of these men by initially limiting the access of clergy to women. Clerical wives were singled out from among all the problems the church had dealt with regarding clerical spiritual impurities, lust, and the consequences from these actions, and instead were harassed as the root of many "preventable" human vices. While church authorities debated and decreed penalties for clerical wives and their children, such as enslavement to the church, ${ }^{90}$ punishments for priests who broke canonical law and disobeyed or outright refused to obey church legislation were often minor or merely threatened. ${ }^{91}$ "But it is inevitable that with a campaign which aimed at nothing less than completely purging a male clergy of their female companions, women in general would become the enemy ... [Thus] clerical wives, not the priests themselves [were presented] as the real transgressors." 92 And yet, even though suppressed and condemned, the priest's wife residing with her priest-husband in his parish was nothing new in the participation of the Christian community during the eleventh and twelfth centuries.

In prior centuries, women had not only been permitted as wives of priests, but were also given special status upon their husband's ordination. "From ancient times she was referred to as presbyteria or sacerdotissa, and according to some rites even received a distinct garb and special

\footnotetext{
${ }^{89}$ Farmer, 539.

${ }^{90}$ Brundage, Law, Sex, and Christian Society, 251.

${ }^{91}$ Elliot, Spiritual Marriage: Sexual Abstinence in Medieval Wedlock (Princeton: Princeton University
} Press, 1993), 102.

92 Ibid. 
blessing," 93 and in "the Gallo-Roman church a clerical wife had been required to take a vow of chastity known as a conversio - in essence consenting to her husband's ordination:"94

Similar arguments were advanced by Innocent I and Gregory I and reinforced by local councils in Italy, Spain, and Gual, where it became common to require the wives of priests to take a vow of chastity at the same time that their husbands did so. One council involved the priests' wives so deeply with their husbands' commitments that they forbade priests' widows to marry again. This was accompanied by a more enforceable vow to occupy separate chambers. ${ }^{95}$

These attitudes toward a married priesthood persisted when Christianity was still in a fledging stage of quickly becoming the dominant religion of Western Europe. Early Christians of the third, fourth, and fifth centuries, still regularly met and worshipped in homes of other Christians, rather than in the stone and decorated parish churches and cathedrals of later centuries. Thus "the congregation was an 'extended family', [sic] . . . and carried out its social services on a one-to-one basis."96 The ritual of the sacrament and the mystery of transubstantiation had not yet fully gained the renown and sacredness it would later receive and therefore did not yet need the sacred and pure hands of a consecrated and chaste priest. ${ }^{97}$ Also, there was no need for a separate and distinct class of men to guide and protect the souls of others as a not fully consecrated minister "earned his living in the community alongside the other congregants, sharing their economic and social problems ... In this small, struggling cult there was as yet no need or desire for a priestly class, set aside from the other believers. Instead, the laity wanted and accepted pastors who lived as they did." 98

The clerical and conjugal couple not only labored beside their lay counterparts in economic and social settings, but also stood as a model for the religious community of what and how married life should appear. As such, "[the priest] and his wife and his children could readily be expected to set a model for the lives of their congregation," 99 since "the village priests and minor clergy were usually married persons, who still slept with their wives [and] . . . were subjected to the same

${ }^{93}$ Elliot, Fallen Bodies, 83-84.

${ }^{94}$ Elliot, Spiritual Marriage, 87.

${ }^{95}$ Jo Ann McNamara, "Chaste Marriage and Clerical Celibacy," in Sexual Practices and the Medieval Church (Buffalo: Prometheus Books, 1982), 25.

${ }^{96}$ Barstow, 20.

${ }^{97}$ Ibid.

${ }^{98}$ Ibid, 20-21.

${ }^{99}$ McNamara, "Chaste Marriage and Clerical Celibacy," 23. 
restraints as were the laity."100 Therefore, married clerical couples were not exempt from the impositions of the church into the sexual lives of its members and had to abide by the same proscriptions as that of lay couples. According to the penitentials, couples could not engage in sexual intercourse if they were not married, if the woman was menstruating, pregnant, or nursing, if it was during Lent, Advent, Whitsun, or Easter week, or on a feast day, fast day, Sunday, Wednesday, Friday, or Saturday, and also if it was daylight, if the couple was naked or in a church, and if the couple did not want a child. ${ }^{101}$

Thus, married clerical couples were not exclusively treated nor elevated to a heightened status in the theology of church authorities. However, clerical couples undoubtedly held esteem within their own communities as models of righteousness and healthy marriages. Providing congregants with not only spiritual guidance, but also practical and experienced relationship advice and skills, clerical couples were more adept at providing nurturance for the whole person, rather than strictly focusing on a person's spirituality and salvation. Clerical couples more than likely also had the ability to sway other community members in the way in which children were raised and instructed, as these families could provide evidence of healthy marriages and family structures. Undoubtedly, though, the actual circumstances of clerical couples probably did not live up to idealistic expectations. For example, in eleventh-century Anglo-Saxon England, enforcement of celibacy legislation was apparently so lax that some priests took more than one wife, or changed sexual partners without actually marrying them. ${ }^{102}$ However, there were also reports of great fidelity among priest's wives who thought of their marriage as "a solemn engagement, fortified with all legal provisions and religious rites, but which [reformers] pronounce[d] a frivolous and meaningless ceremony."

Even though the Second Lateran Council in 1139 decreed that the marriages of priests be dissolved, and both husband and wife do penance, lest priests "be deprived of their clerical positions and benefices," 104 many couples refused to break the oath of marriage, citing the lasting and biblically sanctioned bond between husband and wife. It was not only out of resistance that clerical couples refuse to separate, but also out of their own beliefs and interpretations of scripture.

${ }^{100}$ Peter Brown, The Body and Society: Men, Women and Sexual Renunciation in Early Christianity (New York: Columbia University Press, 1988), 256.

${ }_{101}$ Brundage, Law, Sex, and Christian Society, 152-175.

${ }^{102}$ Henry C. Lea, The History of Sacerdotal Celibacy in the Christian Church (New

York: Russell \& Russell, 1957), 138.

${ }^{103}$ Ibid, 163.

${ }^{104}$ Brundage, Law, Sex, and Christian Society, 220. 
However, reformers continuously slandered those who did not share in their beliefs, and related instances of divine intervention into the lives and deaths of fornicating priests and their wives:

A zealous admirer of Gregory relates with pious gratulation, as indubitable evidence of divine vengeance, how, maddened by their[priest's wives] wrongs, some of them openly committed suicide, while others were found dead in the beds which they had sought in perfect health; and this being proof of their possession by the devil, they were denied Christian sepulture. ${ }^{105}$

But still there were episodes and cases of priests and their wives who were not seemingly punished by a vengeful God. Priest's wives continued to thrive as a substantial part of the Christian community up until the dramatic legislation of the mid-eleventh-century when clerical purity was heavily emphasized and influenced by the ascetic lifestyles of hermit-clerics and transient preachers.

Even though condemned by church councils, the priest's wife continued to play her role as supporter of her religious husband, good mother, and even possibly as an assistant to her husband in his priestly activities. As mentioned before, in early Christianity, upon ordination of her husband, the priest's wife also received a special blessing and clothes, thereby establishing her importance within the functioning of church offices. Some evidence suggests that priest's wives were invested with the office of deaconess, and "it seems safe to assume that many of subsidiary and nonsacramental administrative functions must have fallen on the marital partners of clergymen."106 Therefore, it seems logical to link the priest's wife with her husband's administrative tasks such as keeping ledgers of expenses, reminding her husband of important meetings with congregants such as home visits, giving last rites, or baptisms, and other scheduled events. It also seems logical to give credit to the priest's wife for the care and maintenance of objects related to the priest's office, such as handling and washing priestly vestments, and altar cloths, sweeping and cleaning the altar area, perhaps washing cups and chalices, and even preparing bread for communion.

In twelfth-century Germany, Geroch, Provost of Reichersberg, reported that “priests” wives [were] assisting their husbands in the ministry of the altar," 107 to the apparent surprise and shock of "the faithful."108 While seemingly accepted as the norm in previous centuries, priest's wives

\footnotetext{
${ }^{105}$ Lea, 192.

${ }^{106}$ McNamara, "Chaste Marriage and Clerical Celibacy," 23.

107 Lea, 268.

108 Ibid.
} 
persistently began to dwindle as church authorities attempted to regulate and monitor the social and sexual habits of its servants. The zealous and even, at times, radical legislation beginning in the eleventh and eclipsing the twelfth century proved devastating for the clerical wife, suspending her from clerical culture altogether. ${ }^{109}$ Damian claimed that clerical marriage was heresy and identified it with Nicolaitism, "an obscure first-century sectarian movement among Christians in Ephesus and Pergamon," "110 and also popularized the term among those who refused to abide by celibacy legislation. Damian also popularized "such terms as 'whore' and 'harlot' to describe the wives of priests."111 "Women who had married clerics in good faith, women who were often themselves daughters or granddaughters of priests or bishops, found themselves shorn of social position, driven from their homes, their marriages denounced as immoral from the pulpits, their honor ruined, their families broken, and their commitment to husband and children denounced as scurrilous and sinful." $" 112$

Amid this legislation, more and more priests were discouraged from taking wives or establishing relationships among women, while priests' wives separated from their husbands either through force, obedience, or fear for their husbands' safety and office. The question remains then, where did the clerical wife go, and how did she live the rest of her life? Shortly after the Synod of Pavia in 1022, Bishop Libentius of Hamburg ordered clerical wives to leave town, and the "ladies promptly resettled in nearby villages, [but] where their husbands continued to visit them periodically."113

However, some clerical wives left never to return, but more interestingly, some evidence suggests instances where former priests' wives attached themselves to other clerical figures. In his biography of Robert of Arbrissel, Baudri of Dol reported how Robert did not refuse "unchaste women, concubines, lepers, and the helpless," "114 from joining his community at Fontevraud. According to Bruce L. Venarde, Baudri uses the adjectival form of the word "incestas" to describe "unchaste women," apparently referring to the incestuous relationships of former clerical wives. ${ }^{115}$ It is also known that the second abbess of Fontevraud was married before converting fully to the

${ }^{109}$ For an interesting perspective on the continuation of the presence of the clerical wife in Christian culture after the twelfth-century, see Elliot, Fallen Bodies, p.107-126 (ch. 5, "Avatars of the Priest's Wife).

${ }^{110}$ Brundage, Law, Sex, and Christian Society, 216.

${ }^{111}$ Ibid.

${ }^{112}$ Ibid, 217.

${ }^{113}$ Ibid, 218.

${ }^{114}$ Robert of Arbrissel, 18.

${ }^{115}$ Ibid, 128 n.53. 
religious life, and historians have even suggested that she may have also been a casualty of the reform movement. ${ }^{116}$

Another piece of interesting evidence from this period also points to the emergence of former clerical wives in the monastic culture of the twelfth-century and beyond. Venarde reports on a very substantial spike in foundations and refoundations of monasteries for women beginning in the early twelfth-century. Venarde writes:

There always were, in the time and space considered here, more women desirous of entry into the religious life than there were places for them ... What is remarkable is the degree to which women who wanted to enter monastic life were accommodated, especially in the years circa 1080-circa 1170, when the women themselves frequently seized the initiative. ${ }^{117}$

Although this evidence is circumstantial, it suggests that what added to the growth and development of new nunneries for women may have been an influx of former clerical wives, who, being forced from their husbands and cast away, attached themselves to either charismatic preachers, such as Robert of Arbrissel, or resettled in nearby monasteries. It also seems likely that with so many women wanting acceptance into a monastic house that new houses were formed to accommodate such large numbers of new women:

Before the early twelfth century, only a tiny faction of papal bulls concerned houses of nuns in Western Christendom. The repertory of Philippe Jaffe lists only sixteen bulls addressed to nuns and their houses in the whole tenth century; of over five hundred bulls he sent forth during his thirteen-year pontificate [1073-1085], Gregory VII issued only five . . . The proportion of bulls to or concerning nuns began to rise notably only after about 1120 . . after a great number of nunneries were founded in northwestern [France and England] Europe, appearing to confirm the observation of one historian that "so much papal history now seems more like authority grappling ill-prepared and as best it could with ideas and

${ }^{116}$ Ibid, 28. See also Elliot, Spritual Marriage, 111 n.71, and also Jacques Dalarun, "Robert d'Arbrissel et les femmes," Annales ESC 39 (1984): 1151-1154.

${ }^{117}$ Bruce L. Venarde, Women's Monasticism and Medieval Society: Nunneries in France and England, 890-1215 (Ithaca: Cornell University Press, 1997), xiii. 
inspirations fermenting below." The increased number of papal bulls in the twelfth century reflects new realities - many new nunneries - rather than new (or old) goals. ${ }^{118}$

Whether or not former clerical wives fled to old or new monastic houses, the ideal of the clerical wife as put forth by medieval reformers and current historians needs rethinking. Was the clerical wife a "new" religious vocation as yet unseen by modern historians? Were these women who sought intimate relationships with priests and other clerics seeking an alternative avenue to express their own spirituality? Perhaps a spiritual life that was not adorned with narrow rules such as those followed by monastic women, nor a life strictly demarcated by marriage and motherhood? Perhaps the intentions of the medieval clerical wives were to seek lives in which sacred and secular activities could be blended, and one in which the perimeters of femaleness and womanhood, as defined by the church, could be broken.

The figures, lineages, and names of clerical wives appear infrequently in medieval texts, but her presence permeates the words of church reformers like an unspoken taboo. Therefore, it is within these unspoken, yet protruding subtleties that the image of the clerical wife forms. Accepted from the onset as an asset to early Christian clerics, but later proclaimed as a polluter to the clerical office by church reformers, conceptions of the clerical wife also changed among priests and other clerics themselves who either accepted the traditional model of clerical marriage or who avoided it out of obedience to canonical law or fear of suspension of their office. However, the question still remains: did the lay communities of eleventh and twelfth century Europe really care about clerical marriage in the first place? Early Christian communities in the third, fourth, and fifth centuries regarded their community clerics as only an extension of the lay community, rather than adopting lofty notions of clerical superiority and cleanliness that dominated church thinking profoundly beginning in the eleventh century. Instances of laymen and women retaliating against married clergy arise in medieval letters and other writings, but these only represented a fraction of the thousands of lay communities and parishes in Europe. Clearly, a full picture most likely will never completely surface, as medieval records and stories of the lives of common married (and even non-married) clergy do not flesh out the enormous volumes of history penned by medieval writers. However, what was written down and what does survive regarding clerical wives can be used to assess degrees to which how medieval culture regarded this distinct religious figure, even if it cannot be expressed in a purely definitive argument.

${ }^{118}$ Ibid, 83. 
References

Anselm, Archbishop of Canterbury. The Letters of Saint Anselm of Canterbury. 3 vols. Translated and Annontated by Walter Fröhlich. Kalamazoo: Cistercian Publications, 1990.

Baldwin, John W. "Five Discourses on Desire: Sexuality and Gender in Northern France around 1200." Speculum 66 (Oct. 1991): 797-819.

Balzaretti, Ross. "Men and Sex in Tenth-century Italy." In Masculinity in Medieval Europe, 143-159. London: Addison Wesley Longman Limited, 1999.

Barstow, Anne Llewellyn. Married Priests and the Reforming Papacy: The Eleventh Century Debates. Vol. 12 of Texts and Studies in Religion. New York: The Edwin Mellen Press, 1982.

Beaudette, Paul. "In the World but not of It": Clerical Celibacy as a Symbol of the Medieval Church." In Medieval Purity and Piety: Essays on Medieval Clerical Celibacy and Religious Reform, 23-46. New York: Garland Publishing, 1998.

Braswell, Mary Flowers. The Medieval Sinner: Characterization and Confession in the Literature of the English Middle Ages. London: Associated University Press, 1983.

Brooke, C.N.L. "Gregorian Reform in Action: Clerical Marriage in England, 1050-1200.” Cambridge Historical Journal 12 (1956): 1-21.

Brown, Peter. The Body and Society: Men, Women and Sexual Renunciation in Early Christianity. New York: Columbia University Press, 1988.

Brundage, James A. Law, Sex, and Christian Society in Medieval Europe. Chicago: University of Chicago Press, 1987. 
. "Sex and Canon Law." In Handbook of Medieval Sexuality, 33-50.

New York: Garland Publishing, 1996.

. "Sin, Crime, and the Pleasures of the Flesh: The Medieval Church

Judges Sexual Offences." In The Medieval World, 294-307. London: Routledge, 2001.

Bullough Vern L. and James Brundage. Sexual Practices \& the Medieval Church. Buffalo:

Prometheus Books, 1982.

, eds. Handbook of Medieval Sexuality. New York:

Garland Publishing, Inc., 1996.

Caesarius of Heisterbach. The Dialogue on Miracles. Translated by H. von E. Scott and

C.C. Swinton Bland. 2 vols. New York: Harcourt, Brace and Company, 1929.

"The Canons of the First Lateran Council, 1123." [Online] Internet Medieval Source

Book [accessed 24 April 2004]; available from http://www.fordham.edu/halsall/ basis/lateran1.html.

"The Canons of the Lateran Council of 1059." [Online] University of Southhampton [accessed 24 April 2004]; available from http://lib329.bham.ac.uk/coreRes/ papacy/document/doc_207.htm\#title.

"The Canons of the Second Lateran Council, 1139." [Online] Internet Medieval Source Book [accessed 24 April 2004]; available from http://www.fordham.edu/ halsall/basis/lateran2.html.

Cowdrey, H.E.J., ed. and trans. The Epistolae V agantes of Pope Gregory VII. Oxford: Clarendon Press, 1972. 
The Register of Pope Gregory VII, 1073-1085: An English Translation.

Oxford: Oxford University Press, 2002.

Damian, Peter. Letters 31-60. In The Fathers of the Church, 394. Translated by Owen J. Blum. Washington, D.C.: Catholic University of America Press, 1989.

Duby, Georges. The Knight, the Lady, and the Priest: The Making of Modern Marriage in Medieval France. Translated by Barbara Bray. New York: Pantheon Books, 1983.

DuVal, John, trans and Raymond Eichman. Cuckolds, Clerics, \& Countrymen: Medieval French Fabliaux. Fayetteville: University of Arkansas Press, 1982.

Eichman, Raymond, and John DuVal, eds. and trans. The French Fabliau: B.N. MS. 837. 2 vols. New York: Garland Publishing, 1984.

Elliot, Dyan. Fallen Bodies: Pollution, Sexuality, and Demonology in the Middle Ages. Philadelphia: University of Pennsylvania Press, 1999. . Spiritual Marriage: Sexual Abstinence in Medieval Wedlock. Princeton: University Press, 1993.

Farmer, Sharon. "Persuasive Voices: Clerical Images of Medieval Wives." Speculum 61 (July 1986): 517-543.

Findlen, Paula, et al, eds. Beyond Florence: The Contours of Medieval and Early Modern Italy. Stanford: Stanford University Press, 2003.

Frasseto, Michael, ed. Medieval Purity and Piety: Essays on Medieval Clerical Celibacy and Religious Reform. New York: Garland Publishing, Inc., 1998. 
Geoffrey the Fat, Vita beati Bernardi fundatoris congregationis de Tironio in Gallia, PL 172 (Paris, 1854).

“Gregory VII: Simony and Celibacy 1074.” [Online] Internet Medieval Source Book [accessed 24 April, 2004]; available from http://www.fordham.edu/halsall/ source/g7-reform1.html.

Guibert of Nogent. A Monk's Confession: The Memoirs of Guibert of Nogent, tans, Paul J. Archambault. University Park: Pennsylvania State University Press, 1996.

Hadley, D.M., ed. Masculinity in Medieval Europe. London: Longman, 1999.

Head, Thomas, and Richard Landes, eds. The Peace of God: Social Violence and Religious Response in France around the Year 1000. Ithaca: Cornell University Press, 1992.

Jackson, Peter. “Ælfric and the Purpose of Christian Marriage: A Reconsideration of the Life of Æthelthryth, lines 120-30.” Anglo-Saxon England 29 (2000): 235-260.

Jestice, Phyllis G. "Why Celibacy? Odo of Cluny and the Development of a New Sexual Morality." In Medieval Purity and Piety: Essays on Medieval Clerical Celibacy and Religious Reform, 81-115. New York: Garland Publishing, 1998.

Jong, Mayke de. "Imitatio Morum. The Cloister and Clerical Purity in the Carolingian World." In Medieval Purity and Piety: Essays on Medieval Clerical Celibacy and Religious Reform, 4980. New York: Garland Publishing, 1998.

Keiser, Elizabeth B. Courtly Desire and Medieval Homophobia: The Legitimation of Sexual Pleasure in Cleanness and Its Contexts. New Haven: Yale University Press, 1997.

Kruger, Steven F. "Conversion and Medieval Sexual, Religious, and Racial Categories." In Constructing Medieval Sexuality, 158-179. Minneapolis: University of Minnesota Press, 1997. 
Lanfranc, Archbishop of Canterbury. The Letters of Lanfranc Archbishop of Canterbury.

Edited and Translated by Helen Clover and Margaret Gibson. Oxford: Clarendon Press, 1979.

Lansing, Carol. "Concubines, Lovers, Prostitutes: Infamy and Female Identity in Medieval Bologna." In Beyond Florence: The Contours of Medieval and Early Modern Italy, 85-100. Stanford: Stanford University Press, 2003.

Lea, Henry C. The History of Sacerdotal Celibacy in the Christian Church. New York: Russell \& Russell, 1957.

Lees, Clare A., and Gillian R. Overing. Double Agents: Women and Clerical Culture in Anglo-Saxon England. Philadelphia: University of Pennsylvania Press, 2001.

Linehan, Peter, and Janet L. Nelson, eds. The Medieval World. London: Routledge, 2001.

Lochrie, Karma, et al. Constructing Medieval Sexuality. Vol. 11 of Medieval Cultures. Minneapolis: University of Minnesota Press, 1997.

McLaughlin, Megan. "Secular and Spiritual Fatherhood in the Eleventh Century." In Conflicted Identities and Multiple Masculinities: Men in the Medieval West, 25-43. New York: Garland Publishing, 1999.

McNamara, Jo Ann. "Chaste Marriage and Clerical Celibacy." In Sexual Practices \& the Medieval Church, 22-33. Buffalo: Prometheus Books, 1982.

. "An Unresolved Syllogism: The Search for a Christian Gender System." In Conflicted Identities and Multiple Masculinities: Men in the Medieval West, 1-24. New York: Garland Publishing, 1999.

Moore, R.I. "Family, Community and Cult on the Eve of the Gregorian Reform." 
Transactions of the Royal Historical Society, $5^{\text {th }}$ ser., 30 (1980): 49-69.

Murray Jacqueline, ed. Conflicted Identities and Multiple Masculinities: Men in the Medieval

West. New York: Garland Publishing, Inc., 1999.

- "Mystical Castration: Some Reflections on Peter Abelard, Hugh of

Lincoln and Sexual Control." In Conflicted Identities and Multiple Masculinities: Men in the Medieval West, 73-91. New York: Garland Publishing, 1999.

Nelson, J.L. "Monks, Secular Men and Masculinity, c.900." In Masculinity in Medieval Europe, 121-142. London: Addison Wesley Longman Limited, 1999.

Payer, Pierre J. Sex and the Penitentials: The Development of a Sexual Code, 550-1150. Toronto: University of Toronto Press, 1984.

Remensnyder, Amy G. "Pollution, Purity and Peace: An Aspect of Social Reform between the Late Tenth Century and 1076." In The Peace of God: Social Violence and Religious Response in France around the Year 1000, 280-307. Ithaca: Cornell University Press, 1992.

Robert of Arbrissel. Robert of Arbrissel: A Medieval Religious Life. Translated by Bruce L. Venarde. Washington, D.C.: The Catholic University of America Press, 2003.

Salisbury, John. The Letters of John of Salisbury. Vol. 1. Edited by W.J. Millor, S.J., and H.E. Butler. Oxford: Clarendon Press, 1986.

Salisbury, Joyce E. “Gendered Sexuality.” In Handbook of Medieval Sexuality, 81-102. New York: Garland Publising, 1996.

Schulenburg, Jane Tibbetts. "Gender, Celibacy, and Proscriptions of Sacred Space: Symbol and Practice." In Medieval Purity and Piety: Essays on Medieval Clerical Celibacy and Religious Reform, 353-376. New York: Garland Publishing, 1998. 
Swanson, R.N. “Angels Incarnate: Clergy and Masculinity from Gregorian Reform to Reformation." In Masculinity in Medieval Europe, 160-177. London: Addison Wesley Longman Limited, 1999.

Venarde, Bruce L. Women's Monasticism and Medieval Society: Nunneries in France and England, 890-1215. Ithaca: Cornell University Press, 1997.

Vitalis, Orderic. The Ecclesiastical History. Vol. 2. Edited and Translated by Marjorie Chibnall. Oxford: Clarendon Press, 1972.

- The Ecclesiastical History. Vol. 3. Edited and Translated by Marjorie Chibnall. Oxford: Clarendon Press, 1972.

- The Ecclesiastical History. Vol. 4. Edited and Translated by Marjorie Chibnall. Oxford: Clarendon Press, 1972.

- The Ecclesiastical History. Vol. 6. Edited and Translated by Marjorie Chibnall. Oxford: Clarendon Press, 1972.

Wertheimer, Laura A. "The Ecclesiastical Construction of Illegitimacy in the Middle Ages.” Ph.D. diss., University of California, Santa Barbara, 2000. 